\title{
ACUTE AND CHRONIC GRAFT VERSUS HOST DISEASE AFTER HEMATOPOIETIC STEM CELL TRANSPLANT
}

\author{
'Vaneuza A. M. Funke, ${ }^{2}$ Maria Claudia Rodrigues Moreira, ${ }^{3}$ Afonso Celso Vigorito
}

${ }^{1}$ Professor of Hematology and Head of Adult HSCT center at Federal University of Paraná, ${ }^{2}$ Hematologist at Centro de Transplante de Medula Óssea (CEMO) - National Institute of Cancer (INCA) and Federal University of Rio de Janeiro, ${ }^{3}$ Hematologist and Supervisor of HSCT center at UNICAMP (Campinas, São Paulo)

Correspondence to: Vaneuza Funke - vfunke@gmail.com

\begin{abstract}
Graft versus host disease is one of the main complications of Hematopoietic stem cell, involving about $50 \%$ to $80 \%$ of the patients. Acute GVHD clinical manifestations and therapy is discussed, as well as new NIH criteria for the diagnosis and classification of chronic GVHD. Therapy for both refractory chronic and acute GVHD is an important field of discussion once there is no superiority for the majority of the agents after primary therapy has failed. Hence, this review is meant to be a useful tool of consultation for clinicians who are dealing with this complex complication.
\end{abstract}

Key words: graft versus host disease, hematopoietic stem cell transplant

\section{INTRODUCTION}

Nearly $50 \%$ of Hematopoietic Stem Cell Transplant (HSCT) patients develop graft versus host disease (GVHD), some of them severe, leading to mortality of up to $20 \% 1$. Published data on incidence and severity of GVHD are heterogenous. However, there are estimates that $60-80 \%$ of long-term survivors have some GVHD activity and need long time immunosuppressive therapy after HSCT2.

\section{ACUTE GRAFT VERSUS HOST DISEASE (AGVHD):}

\section{Diagnosis}

In 2005, National Institute of Health (NIH) Consensus document on CGVHD was published with the objective of standardize diagnosis and classification of this disease. [3] The new classification proposed the categories of classic acute GVHD for those patients who developed the characteristic inflammatory syndrome generally before day +100 after HSCT, and the category of late, persistent or recurrent acute GVHD for those patients with no clinical signs of chronic GVHD who developed acute GVHD symptoms after day +100 [3].

\section{Epidemiology and risk factors}

Risk factors for aGVHD were identified by several studies as follows: HLA mismatch, alternative donors (unrelated or haploidentical donors), sex disparity (especially female donor to male patient), myeloablative conditioning regimen, immunophrophylaxis, stem cell source (peripheral blood) [4].

\section{Acute GCHD Clinical Picture}

Skin, gastrointestinal tract $(\mathrm{Gl})$ and liver are the main involved sites affected by aGVHD. Skin is usually the first organ noticed, presenting as a maculopapular erythema frequently involving palms, soles and ear pavilions as well as nape and shoulders. It can disseminate by all over the body surface becoming confluent and pruriginous, sometimes even painful. On severe forms it looks like Stevens-Johnson syndrome, with epidermal necrosis and bullae formation. Superior (esophageal and gastric mucosa) or lower Gl tract (bowel) can be involved. Clinical presentation varies from anorexia, nausea and vomiting to severe diarrhea usually accompanied by abdominal pain, and sometimes bleeding. [5] Severe lower GI tract is 
associated to mortality and lower overall survival in those patients. Stool volume can be higher than 10 liters in 24 hours. 6 Hepatic aGVHD occurs generally in patients with skin or Gl involvement, but it can be rarely isolated. Hepatic and canalicular enzymes (AST, ALT, predominantly conjugated bilirubin, alkaline phosphatase and gamma glutamyl transferase) are elevated. [7]

\section{Acute GVHD staging and classification}

The first staging system for acute GVHD was published in 1974 by Glucksberg et al. [5] Each organ was evaluated according to the severity of involvement and resultant data were globally graded. [5,7] After two decades this classification was reviewed by Keystone aGVHD Consensus, which confirmed the predictive value of severe acute GVHD (II to IV) for mortality rate at day 100 . Furthermore, upper $\mathrm{Gl}$ acute GVHD was recognized and for lower Gl involvement, bleeding and severe pain were included as grade IV aGVHD together with stool volume (table 1). [8]

AGVHD staging is important for evaluating therapy response and correlates to overall survival after HSCT as mentioned before. [9] Patients who develop grade II-IV aGVHD have lower overall survival compared to mild ones (gradel). Upper Gl involvement has better prognosis and better response to low dose steroids than lower Gl acute GVHD. Moderate and severe GVHD are seen in up to $40 \%$ of allogeneic HSCT. [10] Recently an international Consortium for diagnosis and staging of acute GVHD, Mount Sinai Acute GvHD International Consortium (MAGIC), revised those criteria based on a very robust database. Main changes were definition of GI Grade IV acute GVHD and upper Gl acute GVHD. This turned out to be a very important instrument for multicentric transversal and prospective studies and is now recommended by CIBMTR, EBMT and NIH for the classification of acute GVHD. Correlative studies with biomarkers were also possible using this platform. $[11,12]$

\section{ACUTE GVHD THERAPY}

The choice of initial therapy for acute GVHD depends on organs involved, severity of symptoms, and weight of graft versus leukemia effect on the individual clinical context.

\section{Grade I acute GVHD}

Mild acute GVHD (grade I) therapy consists mainly of using topical agents along with optimization of phrophylaxis (serum level of calcineurin inhibitor adjustment). Adjuvant therapy as antihistaminic med- ications can also be used for pruritus control. The is no indication for systemic therapy. [13]

\section{Grade II-IV acute GVHD}

Patients with moderate acute GVHD (grade II-IV) should receive methylprednisolone (MP) or prednisone at a dose of $2 \mathrm{mg} / \mathrm{kg} /$ day. This has been the standard therapy for decades and its effect is related to both lymphocytic and anti-inflammatory effect. [13] At the same time, drugs used as immunophrophylaxis as cyclosporine or tacrolimus should not be discontinued. In a retrospective study of 733 patients, use of MP at lower doses as $1 \mathrm{mg} / \mathrm{kg} /$ day was effective and not harmful for those patients with acute GVHD grade I-Ila. Dose could be escalated to $2 \mathrm{mg} / \mathrm{kg} /$ day when necessary, if symptoms worse within 72 hours. For this subgroup survival was comparable and this approach allowed the use of 50\% steroid doses.14 Use of non-absorbent steroids (beclomethasone e budesonide) has also been used as adjuvant therapy together with systemic steroids for upper or lower acute GVHD. [15,16] About $60 \%$ of patients respond to initial therapy but some of these responses are not durable. [17]

\section{Secondary therapy for acute GVHD grade II-IV}

Progression after three days, no improvement after seven days or no resolution after 14 days of therapy with MP $2 \mathrm{mg} / \mathrm{kg} /$ day associated to calcineurin inhibitor defines steroid refractory acute GVHD and a second line therapy is indicated. Refractory acute GVHD has poor prognosis as secondary therapy is unsuccessful. One year overall survival for this population was only $20-30 \%$. [18]

Few prospective studies have been published with second line agents, but results are hardly comparable due to high heterogeneity among drugs, centers and approaches. Bad quality historical controls are additional obstacles, partially due to low accuracy on grading initial acute GVHD. As there is no superiority of any agent, choice should be guided by factors as previous therapy effects, drug interaction, availability, costs and team experience. Generally, mean response rate is about $50 \%$, and median survival of about $60 \%$ at six months after therapy. [18] Main results published with these agents are summarized below.

\section{Mycophenolate Mofetil (MMF)}

MMF acts through inhibition of guanosine triphosphate synthesis, which is important for lymphocyte proliferation. MMF was one of four drugs tested as initial therapy added to MP at BMT CTN 0302, a ran- 
domized phase II trial. [19] However this association was not superior and had more adverse events when compared to standard therapy at a blinded phase III randomized trial (BMT CTN 0802). There was no difference in GVHD free survival or cumulative incidence of chronic GVHD in 12 months. [20] Retrospective studies using MMF as second line therapy show rates of complete and partial remission of about $77 \%$ in six months and is a clinical option in this scenario. [21, 22]

\section{Extracorporeal Photopheresis (ECP)}

ECP consists of irradiation of circulating lymphocytes collected by apheresis, incubated with the sensitizing agent 8-methoxypsoraleno, and exposed to UVA phototherapy. It induces apoptosis of all cells, including activated T-cells after 24 hours. Reinfusion of these apoptotic cells stimulates antigen presenting cells (APCs), which regulate immune homeostasis through production of anti-inflamatory cytokines and regulatory $T$ cell recruitment and expansion, inducing immune tolerance. [23]

In 2006 a prospective phase II study was published evaluating ECP and included 59 patients with severe steroid refractory or steroid dependent acute GVHD. Complete responses were seen in $82 \%$ of patients with cutaneous involvement, $61 \%$ of those with liver GVHD and $61 \%$ of patients with GI GVHD. [24] No opportunistic infections were observed and there was no increment of relapse rate. [24]

\section{Antithymocyte globulin (ATG)}

These polyclonal antibodies are the most frequently used all over the world for acute GVHD second line therapy. Although there is large experience with this agent for more than three decades, response rates are achieved in only 20 to $30 \%$ of the patients, with poor overall survival of less than $10 \%$. Better responses are seen in cutaneous acute GVHD. $[25,26]$

Anti IL-2 receptor monoclonal antibodies (basiliximab, daclizumab)

These drugs bind to alpha subunit of interleukin 2 receptor (CD25) at activated T lymphocytes. Basiliximab is a chimeric antagonist of IL-2 receptor and has been successfully used as secondary therapy for acute GVHD, achieving up to $71 \%$ of overall response rate in a phase I trial published in 2002 with 17 patients 27 . Funke et al published in 2005 a single center experience in 34 patients with severe acute GVHD (grade III-IV) refractory to steroids. Overall response rate was $80 \%$, and five years overall survival was $30 \% .28$
Tumoral Necrosis Factor Antagonists (Infliximab, Embrel)

These drugs are frequently used as therapy for severe acute GVHD refractory to steroids and involving lower GI tract18. The biggest experience was published by Couriel and cols29, who studied 37 patients diagnosed with refractory acute GVHD and achieved an overall response rate of $70 \%$.

\section{Ruxolitinib}

Formely used as therapy for chronic myeloproliferative disorders (primary myelofibrosis and Policytemia Vera), ruxolitinib inhibits $\gamma$-interferon receptor signalizing. With this rational, it started also to be tested in GVHD patients. Janus kynases. (JAKs) are important effectors in all three recognized acute GVHD pathogenetic phases. Ruxolitinib blocks cytokine production and signalization and regulate development and function of T cells and APCs. Furthermore, Jak-STAT inhibition in pre-clinical models reduced GVHD without compromising GVL. [30, 31]

Two studies were performed sequentially using ruxolitinib as a 2-line therapy for refractory GVHD (grade II-IV). The first called REACH1 (phase II, prospective, single arm) reported a global response (RC $+\mathrm{RP}$ ) of $54.9 \%$ at D28 in a cohort of 49 patients. The dose ranged from 10 to $20 \mathrm{mg}$ / day, with cytopenias and viral reactivation being the main toxicities to the drug. still in need of treatment 31. This study also evaluated overall survival at D180 and reached the percentage of $73 \%$ with only 11 patients (15\%) still in need of treatment after six months. [32]

In 2019, ruxolitinib became the first (and only to date) treatment approved by the FDA (Food and Drug Administration) for corticosteroid refractory aGVHD.

The second study, called REACH 2, was published in April 2020 and was the third phase 3 study described in the literature. It consisted of a multicenter, randomized trial comparing the efficacy and safety of the use of ruxolitinib in the oral dose of $20 \mathrm{mg}$ with a control arm that consisted of one of nine therapies frequently used to rescue corticosteroid disease (this treatment was of the investigator's choice). A total of 309 patients were randomized and the overall response rate at D28 was significantly higher in the ruxolitinib group compared to the control group ( $62 \%$ vs $39 \%$, odds ratio, $2.64,95 \% \mathrm{Cl} 1.65$ to $4.22, \mathrm{P}<0.0001)$. The lasting global response in D56 was also significantly higher in the inhibitor group ( $40 \%$ X $22 \%)$. When extending the follow-up period to 6 months (180 days), a 10\% loss of therapeutic response can be observed in the ruxolitinib group compared to $39 \%$ in the control. [33] 


\section{CHRONIC GRAFT VERSUS HOST DISEASE (CGVHD):}

GVHD is the major cause of late allogeneic HSCT morbidity and mortality, occurring in $30-70 \%$ of patients. [34] The 2-year cumulative incidence of cGVHD, as defined by the National Institute of Health $(\mathrm{NIH})$ criteria, after allogeneic HSCT with bone marrow or peripheral blood from related or unrelated donors, in a study that assessed risk factors for aGVHD and cGVHD was $34 \%$ (range $32 \%-35 \%$ ). [35] The clinical manifestations of CGVHD can be restricted to a single organ or can be disseminated, with a profound impact on quality of life. The pathophysiology of cGVHDc involves inflammation, cellular and humoral immunity and fibrosis. [36] This immunological complication resembles autoimmune diseases with clinical manifestations of collagen vascular diseases, such as oral lichen planus, sicca keratoconjunctivitis, xerostomia, polyserositis, esophagitis and esophageal stenosis, ulceration and vaginal stenosis, intrahepatic obstructive liver disease, obstructive lung disease, scleroderma, fasciitis and myositis. Clinical manifestations almost always appear in the first two years after transplantation. [36]

\section{Chronic GVHD diagnosis and differentiation from acute GVHD}

There were few changes from $2005 \mathrm{NIH}$ consensus to $2014 \mathrm{NIH}$ Consensus on chronic GVHD. [4,37] Acute GVHD includes two categories : (1) Classic acute GVHD, usually within 100 days of HSCT and with no diagnostic or distinctive signs of chronic GVHD; (2) Late, persistent or recurrent acute GVHD, also without signs of chronic GVHD (cGVHD) but occurring later than 100 days of HSCT. For both 2005 and 2014 Consensus documents, chronic GVHD consisted of one of two categories: (1) classic CGVHD, with no signs of acute GVHD; (2) Overlap syndrome, where the patient has concomitant diagnostic or distinctive signs of cGVHD and inflammatory manifestations (liver or Gl activity, skin erythema). This entity was better defined at 2014 consensus. [37] Clinical manifestations, either than timing, will determine the diagnosis of acute or chronic GVHD. Diagnostic symptoms or signs of chronic GCHD are enough for diagnosis, without the need for biopsy or other tests from other organs involved. Lichenoid changes and sclerosis are diagnostic for chronic GVHD. Distinctive signs are defined as those commonly found in chronic GVHD but there is the requirement of a biopsy for confirmation (e.g ocular sicca, vitiligo). [37] For CGVHD diagnosis is necessary at least one diagnostic manifestation or at least one distinctive manifestation confirmed by biopsy or lab tests, spe- cialist evaluation (ophthalmologist, gynecologist) or radiology images, at the same or in another organ, except when contra-indicated. [37]

\section{Clinical organ scoring system}

The scoring system of the 2005 consensus 4 was modified based on the available evidence, or lack of it, and the doubts generated by the researchers and the clinical practice. [37] The organs considered for scoring include skin, mouth, eyes, Gl tract, liver, lungs, joints, fascia and genital tract. Each organ or location is scored on a 4-point scale (0-3) with 0 representing non-involvement and 3 reflecting serious impairment. Several studies have shown that the global severity, by $2005 \mathrm{NHI}$ criteria, at diagnosis, is associated with overall survival and TRM. Some elements of the score were validated as measures of quality of life. [37] The mild, moderate, and severe description of reflects the degree of impact and functional impairment, in each organ or location, due to cGVHD. Tables 2 and 3 summarize NIH consensus clinical score system and global scoring for GVHD.

\section{Chronic GVHD therapy}

Mild asymptomatic GVHD can often be managed with local treatment (eg, topical corticosteroids for skin involvement). In patients with three or more organs, or with a score of 2 or higher, in any organ, systemic treatment should be considered. Although it is associated with a lower relapse rate, cGVHD remains the main cause of late morbidity and mortality in HSCT recipients. [38] The frequent involvement of several organs and the pleomorphic clinical picture of this complication require multidisciplinary management, which includes, in addition to several medical specialties, nutrition, physiotherapy, psychological, dental, social and occupational therapy. [39] Periodic assessment of quality of life is recommended in patients with CGVHD, representing an efficient instrument for response to treatment. [40]

\section{Mild chronic GVHD therapy}

The mild symptomatic form should generally only be treated with topical agents, but data as the underlying disease (malignant or non-malignant) and its status at transplant, presence of high risk factors for mortality associated with GVHDc (thrombocytopenia, progressive onset of the disease) should be considered. [39] In addition, manifestations of mild GVHD that do not respond satisfactorily to topical treatment, such as hepatic GVHD or fasciitis, can be treated with isolated corticotherapy. [39] 


\section{MODERATE AND SEVERE CHRONIC GVHDTHERAPY}

\section{First line therapy}

The criteria defined by NIH Consensus for systemic treatment include: scores $>2$ in one organ, involvement of three or more organs and mild GVHD with high risk characteristics (platelet counts $<100,000 /$ $\mathrm{mm} 3$ and use of immunosuppressants for the diagnosis of GVHD). [37]

The standard initial systemic treatment consists of prednisone $1 \mathrm{mg} / \mathrm{kg} /$ day and cyclosporine (CSA) $10 \mathrm{mg} / \mathrm{kg} /$ day divided into 2 doses, administered orally, with a dose of CSA adjusted by the plasma level. [41] Tacrolimus has also been used to replace cyclosporine with similar responses. Withdrawal should be initiated, if there is a response or stable manifestations, after two weeks of treatment, reducing the dose of prednisone by $25 \%$ each week until reaching, in 6 to 8 weeks, the target dose of $1 \mathrm{mg} / \mathrm{kg}$ every other day, which should be maintained for 2 to 3 months in cases of non-complete response, severe forms or the presence of risk factors. Then, reduce 10 to $20 \%$ per month until total suspension in 9 to 12 months according to tolerance. [41]

Steroid refractory GVHD is defined by disease progression after 2 weeks of therapy (prednisone at a dose of $1 \mathrm{mg} / \mathrm{kg} /$ day); stable disease using prednisone (>0.5 mg / kg / day) for 4-8 weeks or inability to reduce the prednisone dose below $0.5 \mathrm{mg} / \mathrm{kg} /$ day. 49 Indications for second-line treatment include worsening manifestations of GVHD in an organ primarily involved, absence of any response after one month of treatment, or inability to reduce the dose of prednisone below $1 \mathrm{mg} / \mathrm{kg}$ / day within 2 months. [41]

\section{Second line therapy}

Several therapeutic options have been tested in patients with GVHD refractory to first-line treatment. The choice of treatment, therefore, will depend on the toxicity pattern of the medication chosen, the organs involved, the patient's preference and the availability of the transplant center. [41]

The main agents used in the treatment of refractory GVHD are selected in table 4 and summarized below.

\section{Extracorporeal Photopheresis (ECP)}

ECP has been widely used as a second-line therapy for muco-cutaneous CGVHD, with complete response rates above $80 \%$ and significant improvement in cGVHD with sclerosis. Recently, Flowers et. Al42 reported results of a prospective randomized double-blind phase II study in 95 patients with steroid refractory, dependent, or intolerant cGVHD treated with FEC in combination with conventional immunosuppressants. There was no significant difference in the improvement of the total skin score (TSS) at week 12, however, a higher rate of complete and partial responses of GVHD in the skin was observed in the ECP arm compared to the control arm; more patients in the ECP arm had at least a $50 \%$ reduction in the dose of steroids and at least a $25 \%$ reduction in total skin score (TSS) in week 12.42 In the extension study, the group undergoing FEC had a significant improvement in skin score at week 24 when compared to the group without intervention. [43] FEC has the advantage of not increasing the risk of infections and having few adverse effects.

\section{Mycophenolate Mofetil (MMF)}

This immunosuppressant, whose prodrug, mycophenolic acid, interferes with purine synthesis and produces cytostatic effect on T and B lymphocytes, is frequently used in rescue therapy for refractory CGVHD. Global response rates vary between 23 and $79 \%$ of patients in several case series.44 Lopez et. Al45 reported in 2005 the largest series of cases with 35 patients with steroid refractory cGVHD. There was $79 \%$ overall response and 35\% complete responses. Seventy-three percent of patients were able to discontinue immunosuppression after adding this drug and only $3 \%$ of treated patients discontinued due to toxicity.

Rapamicin (mTOR) mammalian receptor inhibitors: sirolimus

These drugs combine immunosuppressive effects and antiproliferative properties in fibroblasts and smooth muscle fibers. There are reports of antineoplastic effects. Sirolimus and everolimus, bind to mTOR forming a complex that induces the cell cycle to stop in $\mathrm{G} 1$ by inhibiting transcription, DNA translation and protein synthesis. In contrast to calcineurin inhibitors, these drugs promote the generation of regulatory $T$ cells. [46]

Jurado et. Al47 published a case series in 2007 of 47 patients who used sirolimus as a secondary treatment in combination with other drugs. The overall response rate was $81 \%$ with $38 \%$ complete responses; $47 \%$ of these patients discontinued immunosuppression and the overall survival was $57 \%$ in three years. Couriel et. Al48 also reported their experience with sirolimus as rescue therapy in 35 patients with cutaneous and visceral GVHD. There was a $63 \%$ global response, $17 \%$ of which were complete and $34 \%$ of patients discontinued immunosuppression. The overall 2 -year survival was $41 \%$. 


\section{Rituximab}

Rituximab binds to the extracellular portion of the $C D$ 20 surface molecule and induces complement-mediated apoptosis and cell death, either directly or through normal or neoplastic B cells. [49] Cutler et. Al50 carried out the first prospective phase I-II study reporting the efficacy of rituximab $(375 \mathrm{mg} / \mathrm{m} 2)$ in 21 patients receiving a total of 38 cycles. Objective responses were observed in $70 \%$ of patients allowing for a significant reduction in the steroid dose. Patients with cutaneous or musculoskeletal manifestations of CGVHD showed a better response. VonBonin et. Al51 used lower doses of $50 \mathrm{mg} / \mathrm{m} 2$ / week for 4 weeks in 11 patients with refractory GVHD and 2 with post-transplant autoimmune disorders (immune glomerulonephritis and thrombocytopenia), observing an overall response rate of $69 \%$, including 3 patients ( $23 \%$ ) with complete remission (CR). Recently, Arai et. Al52 published a prospective randomized study comparing imatinib and rituximab. Significant clinical response was observed in 9 of 35 (26\%, 95\% Cl: $13-43 \%$ ) participants randomized to imatinib and 10 of 37 (27\%, 95\% Cl: $14-44 \%)$ randomized to rituximab.

\section{Imatinib}

Imatinib, an inhibitor of several kinases used successfully in BCR-ABL positive malignancies, has recently been used to treat CGVHD based on its antifibrotic activity by blocking the platelet-derived growth factor (PDGFR) receptor and growth factor beta transformation (TGFß). [53] The main adverse events with this drug include hematological toxicity, water retention, dyspnea, leading to discontinuation of the drug in 15 to $25 \%$ of patients. Responses were observed in $50 \%$ to $80 \%$ of patients with cutaneous, occular and intestinal involvement by CGVHD over a six-month period. In cases of pulmonary involvement, the best responses were seen in mild bronchiolitis. [53]

\section{Low dose Methotrexate}

MTX is an antimetabolite that in low doses has immunomodulatory and anti-inflammatory properties. Giaccone et al54 reported $71 \%$ (10/14) of refractory GVHD control, with a prednisone reduction to dose $<1 \mathrm{mg} / \mathrm{kg}$ / alternate days, with a $7.5 \mathrm{mg} / \mathrm{m} 2$ / week MTX regimen in patients with refractory, long-term GVHD with 5 sites affected on average. At a median follow-up 25 weeks, overall survival rate was $92.8 \%$, and no grade III / IV toxicity was observed. A more recent series of 27 children with refractory GVHD (17 with chronic form) treated with MTX doses of 3-10 $\mathrm{mg}$ / $\mathrm{m} 2$ / week showed $58.8 \%$ overall response, with prednisone suspension on $7 / 17$ and reduction (dose $<0.4 \mathrm{mg} / \mathrm{kg}$ ) in 9/17 patients. [55]

\section{Ibrutinib}

Ibrutinib is a drug of the tyrosine kinase enzyme inhibitor class, with recognized activity in the Bruton's tyrosine kinase (BTK) pathway which is predominantly expressed in the $B$ lymphocytes. It inhibits signal transduction from the $B$ cell receptor leading to blockade of the $B$ cell receptor activation, interruption of the cell cycle and apoptosis. Its role in the treatment of lymphoproliferative malignancies of lineage $B$ had already been recognized through several clinical studies and its use had been approved since 2017 by the FDA.

In addition to the BTK inhibition described above, ibrutinib is also able to alter the function of T lymphocyte through the inhibition of tyrosine kinase stimulated by IL-2 (ITK) which comes to reach T lymphopoiesis. Thus, it leads to decreased cell activation and proliferation of $\mathrm{T}$ lymphocytes, in addition to a decrease in the release of inflammatory cytokines. [56]

The rationale for the use of ibrutinib has led to its applicability as rescue therapy in refractory GVHD. To date, the only therapy approved for GVHD as 2-line by the FDA and recently also approved by ANVISA. A phase 1b / 2 study published by Miklos et al in 2017 used the daily dose of $420 \mathrm{mg}$ in a cohort of 42 patients with a median time to initial response of 87 days. The overall response rate was $67 \%$ and $21 \%$ had CR therapy. About $70 \%$ of patients showed sustained clinical response for $>5$ months after starting the drug. In general, 26 patients in the cohort (62\%) achieved a reduction of corticosteroids dose to $<0.15 \mathrm{mgkg}$ per day during the study. [56]

\section{Ruxolitinib}

The good results observed in GVHD with this agent has stimulated the industry and the results of a prospective phase III trial currently being recruited are awaited. The Spanish Group of Hematopoietic Transplantation and Cell Therapy (GETH) published in 2020 the results of a retrospective study with 56 heavily treated patients, with median of three previous therapies (1-10). The overall response rate was $57.1 \%$ in this adverse clinical group. There was gradual steroid taper and OS was $81 \%$ after 1 year of follow-up. [57] 


\section{REFERENCES}

1. Center for International Blood and Marrow Transplant Research. Current uses and outcomes of hematopoietic stem cell transplantation 2014: summary slides. CIBMTR Web site. http://www.cibmtr. org. Acessado em 11de outubro de 2015.

2. Ferrara JL, Levine JE, Reddy P, et al. Graft-vs-hostdisease. Lancet. 2009;373:1550-1561.

3. Filipovich AH, Weisdorf D, Pavletic S, et al. National Institutes of Health consensus development project on criteria for clinical trials in chronic graft-versus-host disease: I. Diagnosis and staging working group report. Biol Blood Marrow Transplant. 2005; 11:945-56.

4. Flowers ME, Inamoto Y, Carpenter PA, et al. Comparative analysis of risk factors for acute graft-versus-host disease and for chronic graft-versus-host disease according to National Institutes of Health consensus criteria. Blood. 2011; 117: 3214.

5. Glucksberg H, Storb R, Fefer A, et al. Clinical manifestations of graft-versus-host disease in human recipients of marrow from HLA-matched sibling donors. Transplantation. 1974; 18:295.

6. Schwartz JM, Wolford JL,Thornquist MD,et al. Severe gastrointestinal bleeding after hematopoietic cell transplantation,1987-1997:incidence,causes and outcome. Am J Gastroenterol. 2001; 96:385.

7. Ketelsen D,Vogel W, Bethge W,et al. Enlargement of the common bile duct in patients with acute graft-versus-host disease: what does it mean? ARJ Am J Roentgenol.2009;193:W181.

8. Przepiorka D, Weisdorf D,Martin P et al. Consensus Conference on Acute GvHD Grading. Bone Marrow Transplant. 1995; 15:825-828.

9.Rowlings PA, Prezpiorka D, Klein JP et al. IBMTR Severity Index for grading acute graft-vesus-host disease: Retrospective comparison with Glucksberg grade. Br J Haematol. 1997; 97:855-864.

10. Cahn JY, Klein JP, Lee SJ, et al. Prospective evaluation of 2 acute graft-versus-host disease (GVHD) grading systems: a joint Societe Française de Greffe de Moelle et Therapie Cellulaire (SFGM-TC),Dana Farber Cancer Institute (DFCl) and International Bone Marrow Transplant Registry (IBMTR) prospective study. Blood. 2005;106:1495.

11. Harris $A C$,Young $R$,Devine $S$ et al.International multicenter standardization of acute graft-versushost disease clinicaldata collection: a report from the Mount Sinai Acute GVHD International Consortium. Blood Marrow Transplant. 2016; 22: 4-10.

12. Scoemans HM, Lee SJ,Ferrara JL et al. EBMT-NIH-CIBMTR Task Force position statement on standardized terminology \& guidance for graftversus-host disease assessment. Bone Marrow Transplant. 2018; 53:1401-1415.

13. Van Lint MT, Uderzo C, Locasciulli A, et al. Early treatment of acute graft-versus-host disease with high or low-dose 6-methylprednisolone:a multicenter randomized trial from the Italian Group for Bone Marrow Transplantation. Blood 1998;92:2288-2293.

14. Mielcarek M, Storer BE, Boeckh $M$, et al. Initial therapy of acute graft-versus-host disease with low-dose prednisone does not compromise patient outcomes. Blood. 2009;113:2888-2894.

15. Mc Donald GB, Bouvier M, Hockenbery DM, et al. Oral beclomethasone diproprionate for treatment of intestinal graft-versus-host disease: a randomized, controlled trial. Gastroenterology. 1998; 115:28.

16. Hockenbery DM, Cruickshank S, Rodell TC, et al. A randomized, placebo-controlled trial of oral beclomethasone dipropionate as a prednisone-sparing therapy for gastrointestinal graft-versus-host disease. Blood. 2007; 109:4557.

17. Hings IM, Filipovich AH, Miller WJ.et al. Prednisone therapy for acute graft-versus-host disease: short-versus long-term treatment. A prospective randomized trial. Transplantation. 1993;56:577580.

18.Deeg HJ. How I treat refractory acute GVHD. Blood. 2007;109(10):4119-26.

19. Alousi AM., Weisdorf DJ., Logan BR., et al. Blood and Marrow Transplant Clinical Trials Network. Etanercept, mycophenolate, denileukin or pentostatin plus corticosteroids for acute graft-versushost disease: a randomized phase 2 trial from the Blood and Marrow Transplant Clinical Trials Network. Blood 2009;114:511-517.

20. Martin PJ, Rizzo JD, Wingard JR, et al. First- and second-line systemic treatment of acute graft-versus-host disease: recommendations of the American Society of Blood and Marrow Transplantation. Biol Blood Marrow Transplant.2012;18:1150-1163.

21. Furlong T, Martin P, Flowers M.E. et.al. Therapy 
with mycophenolate mofetil for refractory acute and chronic GVHD. Bone Marrow Transplant. 2009; 44:739.

22. Krejci M, Doubek M, Buchler T, et al. Mycophenolate mofetil for the treatment of acute and chronic steroid-refractory photochemoterapy. Ann. Hematol.2005;84:681-685.

23. Gorgun G, Miller KB., Foss F. M., et al. Immunologic mechanisms of extracorporeal photochemoterapy in chronic graft-versus-host disease.Blood 2002;100:941.

24. Greinix HT, Knobler RM, Worel N, et al. The effect of intensified extracorporeal photochemoterapy on long-term survival in patients with severe acute graft-versus-host disease.Haematologica 2006;91:405-408.

25. MacMillan ML, Weisdorf DJ, Davies SM,et al. Early antithymocyte globulin therapy improves survival in patients with steroid-resistant acute graftversus-host disease. Biol Blood Marrow Transplant.2002;8:40-46.

26. Carpenter PA, Sanders JE. Steroid-refractory graftvs-host disease: past, present and future. Pediatr Tansplant. 2003;7(suppl3):19-31.

27. Massenkeil G, Rackwitz S, Genvresse I, et al. Basiliximab is well tolerated and effective in the treatment of steroid refractory acute graft-versushost disease after allogeneic stem cell transplantation. Bone Marrow Transplant.2002;30:899-903.

28. Funke VA, de Medeiros CR, Setúbal DC, et al. Therapy for severe refractory acute graft-versus-host disease with basiliximab, a selective interleukin-2 receptor antagonist. Bone Marrow Transplant. 2006; 37:961-965.

29. Couriel D1, Saliba R, Hicks K, et al. Tumor necrosis factor-alpha blockade for the treatment of acute GVHD. Blood. 2004 Aug 1;104(3):649-54.

30. Schroeder MA, Choi J,Staser K, et al. The role of Janus Kinase signaling in Graft-Versus-Host Disease and Graft Versus Leukemia. Biol Blood Marrow Transplant.2018;24:1125-1134.

31.Choi J,Cooper ML,Alahmari B, et al.Pharmacologic blockade of JAK1/JAK2 reduces GvHD and preserves the graft-versus-leukemia effect.PLoS One 2014;9 (10):e109799.

32. Jagasia $M$, Ali $H$, Schroeder $M$,et al. Ruxolitinib in combination with corticosteroids for the treatment of steroid-refractory acute graft-vs-host-dis- ease: Results from the phase $2 \mathrm{REACH}$ trial. Biol Blood Marrow Transplant. 2019:25 issue3, S52.

33. Zeiser R, Bubnoff N, Butler J, et al. Ruxolitinib for glucocorticoid-refractory acute graft-versus-host disease. N Engl J Med. 2020; 382:1800-1810.

34. Lee SJ, Klein, Barrett AJ et al. Severity of chronic graft-versus-host disease: association with treatment-related mortality and relapse. Blood 2002;1 00:406-414.

35. Flowers $\mathrm{ME}$, Inamoto $\mathrm{H}$, Carpenter PA, Lee SJ, Kiem HP, Petersdorf EW, et al. Comparative Analysis of Risk Factors for Acute Graft-Versus-Host Disease and for Chronic Graft-Versus-Host Disease According to National Institutes of Health Consensus Criteria. Blood. 2011 Mar 17;117(11):3214-9.

36. Wolff $D$, Bertz H, Greinix H, Lawitschka A, Halter J, Holler $\mathrm{E}$. The treatment of chronic graft-versus-host disease: consensus recommendations of experts from Germany, Austria, and Switzerland. Dtsch Ärztebl Int. outubro de 2011;108(43):732-40.

37. Jagasia MH, Greinix HT, Arora M, Williams KM, Wolff D, Cowen EW, et al. National Institutes of Health Consensus Development Project on Criteria for Clinical Trials in Chronic Graft-versusHost Disease: I. The 2014 Diagnosis and Staging Working Group report. Biol Blood Marrow Transplant J Am Soc Blood Marrow Transplant. March 2015;21(3):389-401.

38. Couriel D, Carpenter PA, Cutler C, Bolaños-Meade J, Treister NS, Gea-Banacloche J, et al. Ancillary therapy and supportive care of chronic graft-versus-host disease: national institutes of health consensus development project on criteria for clinical trials in chronic Graft-versus-host disease: V. Ancillary Therapy and Supportive Care Working Group Report. Biol Blood Marrow Transplant J Am Soc Blood Marrow Transplant.2006;12(4):375-96.

39. Martin PJ, Carpenter PA, Sanders JE, Flowers ME. Diagnosis and clinical management of chronic graft-versus-host disease. Int J Hematol. 2004;79(3):221-8.

40. Pidala J, Kurland BF, Chai X, et al. Sensitivity of changes in chronic graft-versus-host disease activity to changes in patient-reported quality of life: results from the Chronic Graft-versus-Host Disease Consortium. Haematologica; 96:1528-35.

41. Flowers MED, Martin PJ. How we treat chronic graft-versus-host disease. Blood. 22 de janeiro de 2015;125(4):606-15. 
42. Flowers MED, Apperley JF, van Besien K, Elmaagacli A, Grigg A, Reddy V, et al. A multicenter prospective phase 2 randomized study of extracorporeal photopheresis for treatment of chronic graft-versus-host disease. Blood.2008;112(7):2667-74.

43. Greinix HT, van Besien $K$, Elmaagacli $A H$, Hillen U, Grigg A, Knobler R, et al. Progressive improvement in cutaneous and extracutaneous chronic graft-versus-host disease after a 24-week course of extracorporeal photopheresis--results of a crossover randomized study. Biol Blood Marrow Transplant J Am Soc Blood Marrow Transplant. 2011;17(12):1775-82.

44. Martin PJ, Storer BE, Rowley SD, Flowers MED, Lee $\mathrm{SJ}$, Carpenter PA, et al. Evaluation of mycophenolate mofetil for initial treatment of chronic graftversus-host disease. Blood. 2009;113(21):5074-82.

45. Lopez F, Parker P, Nademanee A, Rodriguez R, AlKadhimiZ, Bhatia R, et al. Efficacy of mycophenolate mofetil in the treatment of chronic graft-versushost disease. Biol Blood Marrow Transplant J Am Soc Blood Marrow Transplant.2005;11(4):307-13.

46. Zeiser $R$, Nguyen VH, Beilhack $A$, Buess $M$, Schulz S, Baker J, et al. Inhibition of CD4+CD25+ regulatory $\mathrm{T}$-cell function by calcineurin-dependent interleukin-2 production. Blood. 2006;108(1):390-9.

47. Jurado $M$, Vallejo $C$, Pérez-Simón JA, Brunet $S$, Ferra C, Balsalobre P, et al. Sirolimus as part of immunosuppressive therapy for refractory chronic graft-versus-host disease. Biol Blood Marrow Transplant J Am Soc Blood Marrow Transplant. 2007;13(6):701-6.

48. Couriel DR, Saliba R, Escalón MP, Hsu Y, Ghosh $S$, Ippoliti $C$, et al. Sirolimus in combination with tacrolimus and corticosteroids for the treatment of resistant chronic graft-versus-host disease. $\mathrm{Br} J$ Haematol. 2005;130(3):409-17.

49. Canninga-van Dijk MR, van der Straaten HM, Fijnheer R, Sanders CJ, van den Tweel JG, Verdonck
LF. Anti-CD20 monoclonal antibody treatment in 6 patients with therapy-refractory chronic graftversus-host disease. Blood. 2004;104(8):2603-6.

50. Cutler C, Miklos D, Kim HT, Treister N, Woo S-B, Bienfang $D$, et al. Rituximab for steroid-refractory chronic graft-versus-host disease. Blood. 2006;108(2):756-62.

51. Von Bonin $M$, Oelschlägel U, Radke J, Stewart $M$, Ehninger $G$, Bornhauser $M$, et al. Treatment of chronic steroid-refractory graft-versus-host disease with low-dose rituximab. Transplantation.2008;86(6):875-9.

52. Arai S, Pidala J, Pusic I, Chai X, Jaglowski S, Khera $\mathrm{N}$, et al. A randomized phase II crossover study of imatinib or rituximab for cutaneous sclerosis after hematopoietic cell transplantation. Clin Cancer Res Off J Am Assoc Cancer Res.2015;

53. Olivieri A, Locatelli F, Zecca M, Sanna A, Cimminiello $M$, Raimondi $R$, et al. Imatinib for refractory chronic graft-versus-host disease with fibrotic features. Blood.2009;114(3):709-18.

54. Giaccone L, Martin P, Carpenter P, Moravec C, Hooper H, Funke V a. M, et al. Safety and potential efficacy of low-dose methotrexate for treatment of chronic graft-versus-host disease. Bone Marrow Transplant. 2005;36(4):337-41.

55. Inagaki J, Nagatoshi $\mathrm{Y}$, Hatano M, Isomura N, Sakiyama M, Okamura J. Low-dose MTX for the treatment of acute and chronic graft-versus-host disease in children. Bone Marrow Transplant. 2008;41(6):571-7.

56. Lazar B and Jaglowski S M.How ibritinib, a B-cell malignancy drug,became an FDA -approved second-line therapy for steroid-resistant chronic GVHD. Blood advances. 2018-volume 2, number 15

57. Gomez VE,Garcia-Gutierrez V,Corral L et al.Ruxolitinib in refractory acute and chronic graft-versus-host disease: a multicenter survey study. Bone Marrow Transplant. 2020; 55:641-48. 
Table 1 - Comparison of the different guidelines available for acute GvHD assessment: individual organ severity staging 12

\begin{tabular}{|c|c|c|c|}
\hline $\begin{array}{l}\text { Organ } \\
\text { Severity } \\
\text { Stage }\end{array}$ & Original Glucksberg criteria & $\begin{array}{l}\text { "Modified Glucksberg" or } \\
\text { "Keystone" } \\
\text { criteria and IBMTR criteria }\end{array}$ & MAGIC criteria \\
\hline $\begin{array}{c}\text { Skin } \\
0 \\
1 \\
2 \\
3 \\
4\end{array}$ & $\begin{array}{c}\text { No rash } \\
\text { Rash }<25 \% \text { of BSA } \\
\text { Rash } 25 \% \text { to } 50 \% \text { of BSA } \\
\text { Rash }>50 \% \text { of BSA } \\
\text { Generalized erythroderma } \\
\text { with bullous formation }\end{array}$ & $\begin{array}{c}\text { No rash } \\
\text { Rash }<25 \% \text { of BSA } \\
\text { Rash } 25 \% \text { to } 50 \% \text { of BSA } \\
\text { Rash }>50 \% \text { of BSA } \\
\text { Generalized erythroderma } \\
\text { with bullous formation }\end{array}$ & $\begin{array}{c}\text { No rash } \\
\text { Rash }<25 \% \text { of BSA } \\
\text { Rash } 25 \% \text { to } 50 \% \text { of BSA } \\
\text { Rash }>50 \% \text { of BSA } \\
\text { Generalized erythroderma } \\
\text { with bullous formation }\end{array}$ \\
\hline $\begin{array}{l}\text { Liver } \\
0 \\
1 \\
2 \\
3 \\
4\end{array}$ & $\begin{array}{l}\text { Total serum bilirubin }<34 \mu \mathrm{mol} / \mathrm{L} \\
\quad(<2 \mathrm{mg} / \mathrm{dL}) \\
\text { or AST/SGOT } 150-750 \mathrm{IU} \\
\text { Total serum bilirubin } 34-50 \mu \mathrm{mol} / \mathrm{L} \\
\text { ( } 2 \text { to } 3 \mathrm{mg} / \mathrm{dL}) \\
\text { Total serum bilirubin } 51-102 \mu \mathrm{mol} / \mathrm{L} \\
\text { ( } 3.1 \text { to } 6 \mathrm{mg} / \mathrm{dL}) \\
\text { Total serum bilirubin } 103-255 \mu \mathrm{mol} / \mathrm{L} \\
\text { ( } 6.1 \text { to } 15 \mathrm{mg} / \mathrm{dL}) \\
\text { Total serum bilirubin }>255 \mu \mathrm{mol} / \mathrm{L} \\
(>15 \mathrm{mg} / \mathrm{dL})\end{array}$ & $\begin{array}{c}\text { Total serum bilirubin }<34 \mu \mathrm{mol} / \mathrm{L} \\
(<2 \mathrm{mg} / \mathrm{dL}) \\
\text { Total serum bilirubin } 34-50 \\
\mu \mathrm{mol} / \mathrm{L} \\
(2 \text { to } 3 \mathrm{mg} / \mathrm{dL}) \\
\mu \mathrm{mol} / \mathrm{L} \\
\text { Total serum bilirubin } 51-102 \\
(3.1 \text { to } 6 \mathrm{mg} / \mathrm{dL}) \\
\mu \text { bilirubin } 103-255 \\
\text { Total serum } / \mathrm{L} \\
(6.1 \text { to } 15 \mathrm{mg} / \mathrm{dL}) \\
\text { Total serum bilirubin }>255 \\
\mu \mathrm{mol} / \mathrm{L} \\
(>15 \mathrm{mg} / \mathrm{dL})\end{array}$ & $\begin{array}{c}\text { Total serum bilirubin }<34 \mu \mathrm{mol} / \mathrm{L} \\
\quad(<2 \mathrm{mg} / \mathrm{dL}) \\
\text { Total serum bilirubin } 34-50 \mu \mathrm{mol} / \mathrm{L} \\
\text { ( } 2 \text { to } 3 \mathrm{mg} / \mathrm{dL}) \\
\text { Total serum bilirubin } 51-102 \mu \mathrm{mol} / \mathrm{L} \\
\text { ( } 3.1 \text { to } 6 \mathrm{mg} / \mathrm{dL}) \\
\text { Total serum bilirubin } 103-255 \mu \mathrm{mol} / \mathrm{L} \\
\text { ( } 6.1 \text { to } 15 \mathrm{mg} / \mathrm{dL}) \\
\text { Total serum bilirubin }>255 \mu \mathrm{mol} / \mathrm{L} \\
(>15 \mathrm{mg} / \mathrm{dL})\end{array}$ \\
\hline $\begin{array}{l}\text { Upper GI } \\
0 \\
1\end{array}$ & $\begin{array}{l}\text { NA } \\
\text { NA }\end{array}$ & $\begin{array}{c}\text { No persistent nausea and no } \\
\text { histologic } \\
\text { evidence of GvHD in the stomach } \\
\text { or } \\
\text { duodenum } \\
\text { Persistent nausea with histologic } \\
\text { evidence of GvHD in the stomach } \\
\text { or duodenum }\end{array}$ & $\begin{array}{c}\text { No or intermittent anorexia or nausea } \\
\text { or vomiting } \\
\text { Persistent anorexia or nausea or } \\
\text { vomiting }\end{array}$ \\
\hline $\begin{array}{c}\text { Lower Gl } \\
0 \\
1 \\
2 \\
3 \\
4\end{array}$ & $\begin{array}{l}\text { Diarrhea }<500 \mathrm{~mL} / \text { day } \\
\text { Diarrhea }>500 \mathrm{~mL} / \text { day } \\
\text { Diarrhea }>1000 \mathrm{~mL} / \text { day } \\
\text { Diarrhea }>1500 \mathrm{~mL} / \text { day } \\
\text { Diarrhea }>2000 \mathrm{~mL} / \text { day }\end{array}$ & $\begin{array}{c}\text { Diarrhea }<500 \mathrm{~mL} / \text { day } \\
\text { Diarrhea }>500 \mathrm{~mL} / \text { day } \\
\text { Diarrhea }>1000 \mathrm{~mL} / \text { day } \\
\text { Diarrhea }>1500 \mathrm{~mL} / \text { day } \\
\text { Severe abdominal pain with or } \\
\text { without ileus }\end{array}$ & $\begin{array}{c}\text { Diarrhea }<500 \mathrm{~mL} / \text { day } \\
\text { or }<3 \text { episodes/day for adultsb,c } \\
\text { Diarrhea } 500-999 \mathrm{~mL} / \text { day } \\
\text { or 3-4 episodes/day for adultsb,d } \\
\text { Diarrhea } 1000-1500 \mathrm{~mL} / \text { day } \\
\text { or 5-7 episodes/day for adultsb,e } \\
\text { Diarrhea }>1500 \mathrm{~mL} / \text { day } \\
\text { or }>7 \text { episodes/day for adultsb,f } \\
\text { Severe abdominal pain with or without } \\
\text { ileus or } \\
\text { grossly bloody stools (regardless of } \\
\text { stool volume) }\end{array}$ \\
\hline $\begin{array}{l}\text { Karnofsky } \\
\text { Index }\end{array}$ & $\begin{array}{l}>30 \% \\
<30 \%\end{array}$ & & \\
\hline
\end{tabular}

AST (Aspartate transaminase); BSA (Body surface area); GI (Gastro-intestinal tract); GvHD (Graft versus Host Disease); IBMTR (International Bone Marrow Transplantation Registry); IU (International units); MAGIC (Mount Sinai Acute GvHD International Consortium); NA (Not applicable); SGOT (Serum glutamic oxaloacetic acid transaminase)

aTo be suggestive for GVHD: anorexia should be accompanied by weight loss, nausea should last at least 3 days, or be accompanied by at least 2 vomiting episodes per day for at least 2 days [16]

bOne episode of diarrhea is considered to be about $200 \mathrm{ml}$ for an adult and $3 \mathrm{ml} / \mathrm{kg}$ for a child $(<50 \mathrm{~kg})[16]$

cDiarrhea $<10 \mathrm{~mL} / \mathrm{kg} /$ day or $<4$ episodes/day for children

dDiarrhea $10-19.9 \mathrm{~mL} / \mathrm{kg} /$ day or 4-6 episodes/day for children

eDiarrhea $20-30 \mathrm{~mL} / \mathrm{kg} /$ day or $7-10$ episodes/day for children

fDiarrhea $>30 \mathrm{~mL} / \mathrm{kg} /$ day or $>10$ episodes/day for children 
Table2 - Scoring system for chronic GVHD37

\begin{tabular}{|c|c|c|c|c|}
\hline & SCORE 0 & SCORE 1 & SCORE 2 & SCORE 3 \\
\hline $\begin{array}{l}\text { PERFORMANCE } \\
\text { SCORE: } \\
\begin{array}{|l} \\
\text { KPS ECOG LPS }\end{array}\end{array}$ & $\begin{array}{l}\text { Asymptomatic and } \\
\text { fully active (ECOG } \\
0 ; \text { KPS or LPS } \\
100 \% \text { ) }\end{array}$ & $\begin{array}{l}\text { Symptomatic, } \\
\text { fully ambulatory, } \\
\text { restricted only in } \\
\text { physically } \\
\text { strenuous activity } \\
\text { (ECOG } 1, \text { KPS } \\
\text { or LPS } 80-90 \% \text { ) }\end{array}$ & $\begin{array}{l}\text { Symptomatic, } \\
\text { ambulatory, capabl } \\
\text { of self-care, }>50 \% \\
\text { of waking hours ou } \\
\text { of bed (ECOG 2, } \\
\text { KPS or LPS } 60- \\
70 \% \text { ) }\end{array}$ & $\begin{array}{l}\text { Symptomatic, } \\
\text { limited self-care, } \\
>50 \% \text { of waking } \\
\text { hours in bed (ECOG } \\
3-4, \text { KPS or LPS } \\
<60 \%)\end{array}$ \\
\hline \multicolumn{5}{|l|}{ SKIN $\dagger$} \\
\hline \multicolumn{5}{|c|}{$\begin{array}{l}\text { Maculopapular rash/erythema } \\
\text { Lichen planus-like features } \\
\text { Sclerotic features } \\
\text { Papulosquamous lesions or } \\
\text { ichthyosis } \\
\text { Keratosis pilaris-like GVHD }\end{array}$} \\
\hline $\begin{array}{l}\text { SKIN FEATURES } \\
\text { SCORE: }\end{array}$ & $\begin{array}{l}\text { No sclerotic } \\
\text { features }\end{array}$ & & $\begin{array}{l}\text { Superficial } \\
\text { sclerotic features } \\
\text { "not hidebound" } \\
\text { (able to pinch) }\end{array}$ & $\begin{array}{l}\text { heck all that apply: } \\
\text { Deep sclerotic } \\
\text { features } \\
\text { "Hidebound" } \\
\text { (unable to pinch) } \\
\text { Impaired mobility } \\
\text { Ulceration }\end{array}$ \\
\hline
\end{tabular}

Other skin GVHD features (NOT scored by BSA)

\section{Check all that apply:}

Hyperpigmentation

Hypopigmentation

Poikiloderma

Severe or generalized pruritus

Hair involvement

Nail involvement

Abnormality present but explained entirely by non-GVHD documented cause (specify):

\begin{tabular}{|c|c|c|c|c|}
\hline $\begin{array}{l}\text { MouTH } \\
\text { Lichen planus-like } \\
\text { features present: } \\
\text { Yes } \\
\text { No }\end{array}$ & No symptoms & $\begin{array}{l}\text { Mild symptoms } \\
\text { with disease signs } \\
\text { but not limiting } \\
\text { oral intake } \\
\text { significantly }\end{array}$ & \begin{tabular}{l}
\multicolumn{1}{c}{ Moderate } \\
symptoms with \\
disease signs with \\
partial limitation \\
of oral intake
\end{tabular} & $\begin{array}{l}\text { Severe symptoms with } \\
\text { disease signs on } \\
\text { examination with major } \\
\text { limitation of oral intake }\end{array}$ \\
\hline
\end{tabular}




\begin{tabular}{|c|c|c|c|c|}
\hline & SCORE 0 & SCORE 1 & SCORE 2 & SCORE 3 \\
\hline $\begin{array}{l}\text { EYES } \\
\text { Keratoconjunctivitis } \\
\text { sicca (KCS) confirmed } \\
\text { by ophthalmologist: } \\
\quad \text { Yes } \\
\quad \text { No } \\
\quad \text { Not examined }\end{array}$ & No symptoms & $\begin{array}{l}\text { Mild dry eye } \\
\text { symptoms not } \\
\text { affecting ADL } \\
\text { (requirement of } \\
\text { lubricant eye } \\
\text { drops } \leq 3 \times \text { per } \\
\text { day) }\end{array}$ & $\begin{array}{l}\text { Moderate dry eye } \\
\text { symptoms partially } \\
\text { affecting ADL } \\
\text { (requiring lubricant } \\
\text { eye drops }>3 \times \text { per } \\
\text { day or punctal } \\
\text { plugs), } \\
\text { WITHOUT new } \\
\text { vision impairment } \\
\text { due to KCS }\end{array}$ & $\begin{array}{l}\text { Severe dry eye } \\
\text { symptoms significantly } \\
\text { affecting ADL (special } \\
\text { eyeware to relieve pain) } \\
\text { OR unable to work } \\
\text { because of ocular } \\
\text { symptoms OR loss of } \\
\text { vision due to KCS }\end{array}$ \\
\hline
\end{tabular}

Abnormality present but explained entirely by non-GVHD documented cause (specify):

\begin{tabular}{|c|c|c|c|c|}
\hline $\begin{array}{l}\text { GI Tract } \\
\text { Check all that apply: } \\
\text { Esophageal web/ } \\
\text { proximal stricture } \\
\text { or ring } \\
\text { Dysphagia } \\
\text { Anorexia } \\
\text { Nausea } \\
\text { Vomiting } \\
\text { Diarrhea } \\
\text { Weight loss } \geq 5 \% * \\
\text { Failure to thrive } \\
\text { Abnormality presen }\end{array}$ & 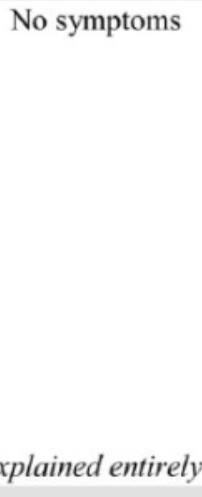 & $\begin{array}{l}\text { Symptoms } \\
\text { without } \\
\text { significant weight } \\
\text { loss* }(<5 \%)\end{array}$ & $\begin{array}{l}\text { Symptoms } \\
\text { associated with } \\
\text { mild to moderate } \\
\text { weight loss* } \\
(5-15 \%) \text { OR } \\
\text { moderate diarrhea } \\
\text { without } \\
\text { significant } \\
\text { interference with } \\
\text { daily living }\end{array}$ & $\begin{array}{l}\text { Symptoms associated } \\
\text { with significant weight } \\
\text { loss* }>15 \% \text {, requires } \\
\text { nutritional supplement for } \\
\text { most calorie needs OR } \\
\text { esophageal dilation OR } \\
\text { severe diarrhea with } \\
\text { significant interference } \\
\text { with daily living }\end{array}$ \\
\hline LIVER & $\begin{array}{l}\text { Normal total } \\
\text { bilirubin and } \\
\text { ALT or AP } \\
<3 \times \text { ULN }\end{array}$ & $\begin{array}{l}\text { Normal total } \\
\text { bilirubin with ALT } \\
\geq 3 \text { to } 5 \times \text { ULN or } \\
\overline{A P} \geq 3 \times \text { ULN }\end{array}$ & $\begin{array}{l}\text { Elevated total } \\
\text { bilirubin but } \\
\leq 3 \mathrm{mg} / \mathrm{dL} \text { or } \\
\text { ALT }>5 \text { ULN }\end{array}$ & $\begin{array}{l}\text { Elevated total } \\
\text { bilirubin }>3 \mathrm{mg} / \mathrm{dL}\end{array}$ \\
\hline \multicolumn{5}{|c|}{ Abnormality present but explained entirely by non-GVHD documented cause (specify): } \\
\hline $\begin{array}{l}\text { LUNGS** } \\
\text { Symptom score: }\end{array}$ & No symptoms & $\begin{array}{l}\text { Mild symptoms } \\
\text { (shortness of } \\
\text { breath after } \\
\text { climbing one flight } \\
\text { of steps) }\end{array}$ & $\begin{array}{l}\text { Moderate } \\
\text { symptoms } \\
\text { (shortness of breath } \\
\text { after walking on } \\
\text { flat ground) }\end{array}$ & $\begin{array}{l}\text { Severe symptoms } \\
\text { (shortness of breath at } \\
\text { rest; requiring } 0_{2} \text { ) }\end{array}$ \\
\hline$\frac{\text { Lung score: }}{\% \mathrm{FEV} 1}$ & $\mathrm{FEV} 1 \geq 80 \%$ & FEV1 60-79\% & FEV1 40-59\% & FEV1 $\leq 39 \%$ \\
\hline $\begin{array}{c}\text { Pulmonary function te } \\
\text { Not performed } \\
\text { Abnormality presen }\end{array}$ & in & 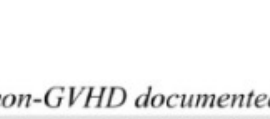 & 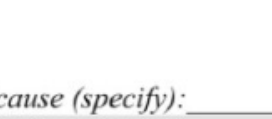 & \\
\hline
\end{tabular}




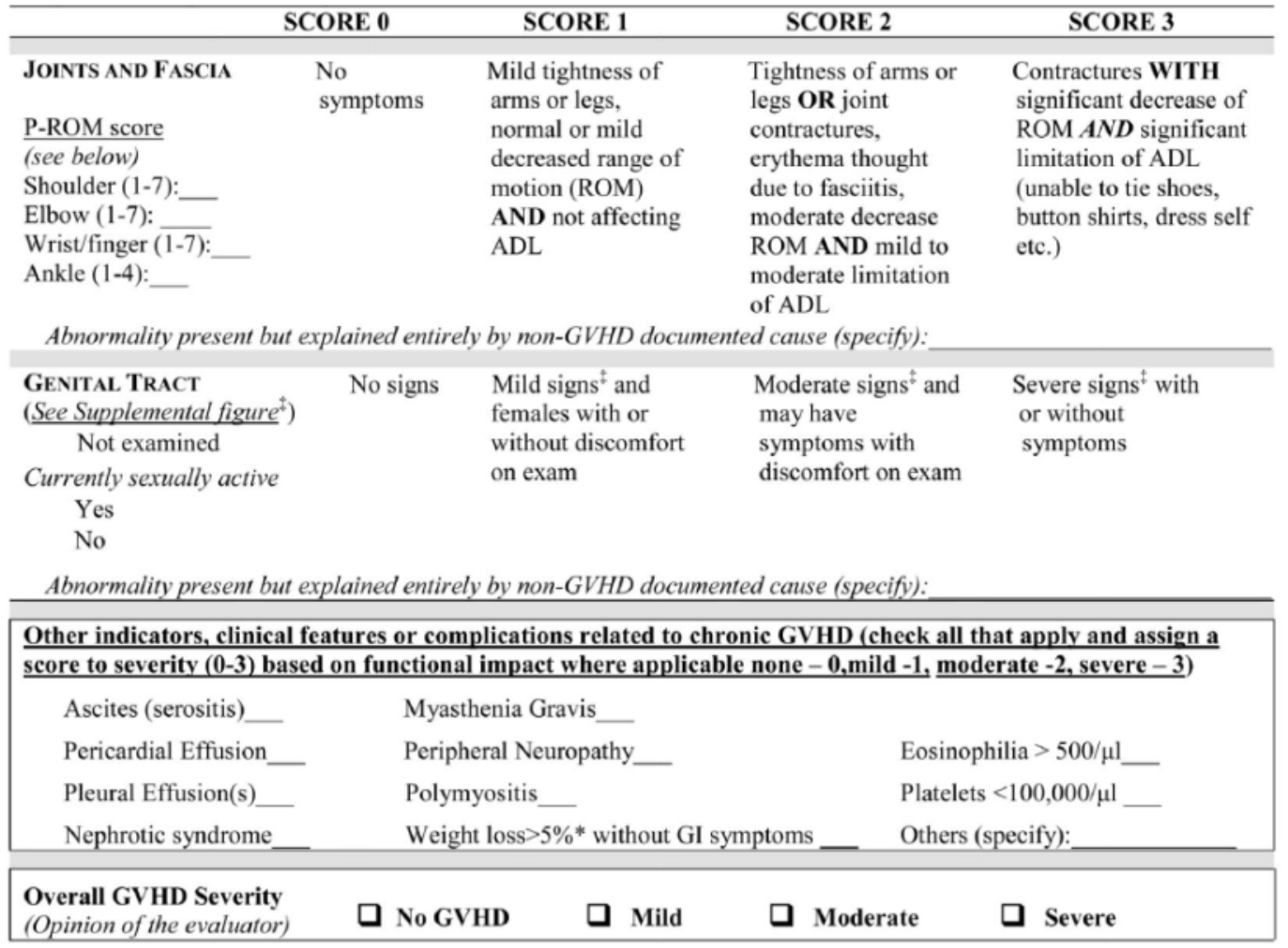

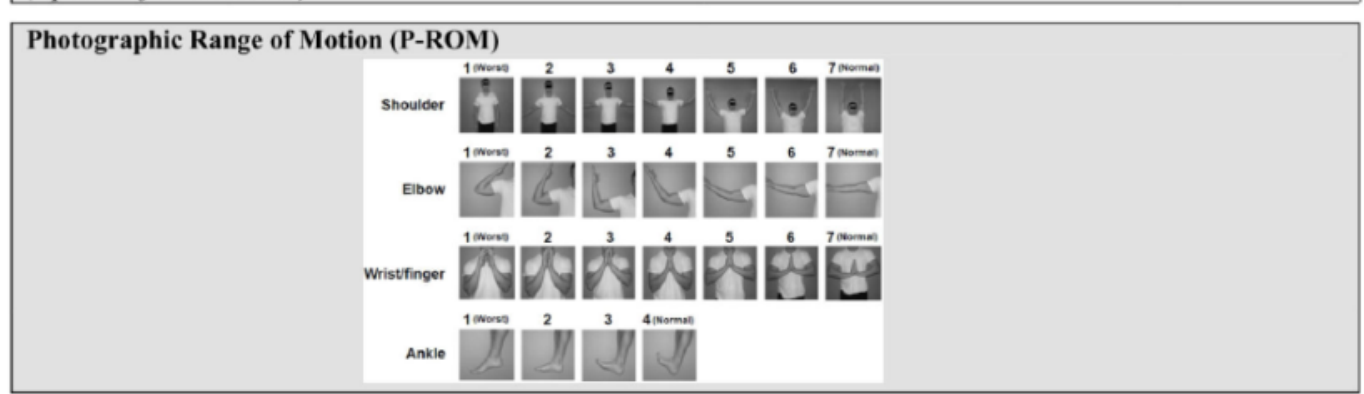

† Skin scoring should use both percentage of BSA involved by disease signs and the cutaneous features scales. When a discrepancy exists between the percentage of total body surface (BSA) score and the skin feature score, OR if superficial sclerotic features are present (Score 2), but there is impaired mobility or ulceration (Score 3), the higher level should be used for the final skin scoring.

* Weight loss within 3 months.

** Lung scoring should be performed using both the symptoms and FEV1 scores whenever possible. FEV1 should be used in the final lung scoring where there is discrepancy between symptoms and FEV1 scores.

Abbreviations: ECOG (Eastern Cooperative Oncology Group), KPS (Karnofsky Performance Status), LPS (Lansky

Performance Status); BSA (body surface area); ADL (activities of daily living); LFTs (liver function tests); AP (alkaline phosphatase); ALT (alanine aminotransferase); ULN (normal upper limit).

$\$$ To be completed by specialist or trained medical providers (see Supplemental Figure). 
Table 3 - GVHD severity

\begin{tabular}{|c|c|}
\hline $\begin{array}{c}\text { Mild chronic GVHD } \\
1 \text { or } 2 \text { organs involved plus } \\
\text { Score } 1 \text { of involved sites plus } \\
\text { Lung score } 0 \\
\text { Severe chronic GVHD } \\
\text { At least one organ with score } 3 \\
\text { or Lung score } 2 \text { or } 3\end{array}$ & $\begin{array}{c}\text { DECH crônica moderada } \\
3 \text { or more site plus } \\
\text { score } 1 \text { of involved sites } \\
\text { or At least one site (except lung) with score } 2 \\
\text { or Lung score } 1\end{array}$ \\
\hline \multicolumn{2}{|c|}{$\underline{\text { Key Points: }}$} \\
\hline $\begin{array}{r}\text { 1. On the skin: The highe } \\
\text { 2. In the lung: FEV1 is used in pla } \\
\text { 3. If an organ abnormality is unequivocally } \\
\text { will be zerc } \\
\text { 4. If an organ abnormality is attributed to } \mathrm{m} \\
\text { used to calculate the overall severity regardle }\end{array}$ & $\begin{array}{l}\text { to calculate the overall severity. } \\
\text { re for the calculation of overall severity. } \\
\text { not associated with GVHD, the score of this organ } \\
\text { f global severity. } \\
\text { GVHD plus other causes) the organ's score will be } \\
\text { g causes (the organ's score will not be disregarded). }\end{array}$ \\
\hline
\end{tabular}

Table 4 - Secondary therapy for chronic GVHD

\begin{tabular}{ccc}
\hline TREATMENT & \% OVERALL RESPONSE & SURVIVAL \\
\hline ECP & $65-70$ & $70 \%-78 \%$ at $1 \mathrm{y}$ \\
\hline Rituximab & $66-86$ & $72 \%$ at $1 \mathrm{y}$ \\
\hline Imatinib & $22-79$ & $75 \%-84 \%$ at $1.5 \mathrm{y}$ \\
\hline Mycophenolate mofetil & $26-64$ & $67 \%-96 \%$ at $1 \mathrm{y}$ \\
\hline MTOR inhibitor & 76 & $72 \%$ at $3 \mathrm{y}$ \\
\hline Low dose methotrexate & $71 \%$ & $92,8 \%$ in 25 weeks \\
\hline Ruxolitinib & $57 \%$ & $81 \%$ at $1 \mathrm{y}$ \\
\hline Ibrutinib & $67 \%$ & Not reported \\
\hline
\end{tabular}

